\title{
Ornithine Transcarbamylase Deficiency in Mutant Mice I. Studies on the Characterization of Enzyme Defect and Suitability as Animal Model of Human Disease
}

\author{
I. A. QURESHI, J. LETARTE, AND R. OUELLET \\ Centre de Recherche Pédiatrique, Hôpital Sainte-Justine and Departement de Pediatrie, Université de Montréal, \\ Montréal, Québec, Canada
}

\section{Summary}

Eighty-four young mice born from matings of four sparse-fur (spf)/+ females and two $22 \mathrm{~A}+/ \mathrm{Y}$ males, were classified according to spf phenotype for males and orotic acid excretion and ornithine transcarbamylase (OTC) activity for females. The OTC activity of $15.2 \pm 1.32 \mu$ mole citrulline $/ \mathrm{mg}$ protein/hr shown by hemizygous affected males was $13 \%$ of that of normal males. Heterozygous females showed a much wider variation with a mean activity of $56 \%$ of normals.

Apparent $K_{m}$ and $V_{\max }$ of the liver OTC in respect of carbamyl phosphate (CP) and ornithine (ORN) were measured for the hemizygous affected males, heterozygous females, and normal males and females. $K_{m}$ and $V_{\max }(C P)$ for hemizygous affected males were significantly lower than normal males, normal females, and heterozygous females. Mean $K_{m}$ and $V_{\max }$ (CP) values of heterozygous females were also significantly different from normal groups and hemizygous affected males. There were no significant differences for the values of $K_{m}$ (ORN) among various groups. However, the $V_{\max }(\mathrm{ORN})$ of hemizygous males was significantly lower than the other three groups. $V_{\max }(\mathrm{ORN})$ of the heterozygous females was also lower than the normal groups.

Mean value of $18.38 \pm 5.13 \mu$ mole orotic acid $/ \mathrm{mg}$ creatinine, excreted by spf/Y males, was significantly higher than all other groups. The average excretion of $7.38 \pm 5.63 \mu$ mole by heterozygous females was also significantly higher than normal males $(0.72$ $\pm 0.23 \mu$ mole) and females $(0.54 \pm 0.27 \mu$ mole $)$. The high orotic acid excretion by mutant mice underlines the basic similarity of these animals to the human counterpart.

There was no significant difference in the excretion of urinary urea between normal males and affected hemizygous males, or between normal females and heterozygous females.

\section{Speculation}

Lower $K_{m}$ for carbamyl phosphate might be a characteristic of OTC from mutant mice with spf gene, which could be detected by urinary orotic acid measurement. These mice would prove to be useful animal models for studying nutritional and therapeutic measures to alleviate the consequences of OTC deficiency in children. Characterization of the defect of a mutant enzyme in an animal model should lead to greater understanding of the human disease counterpart. These studies would also be helpful in investigation of other inherited hyperammonemic syndromes.

In 1976, Demars et al. (9) reported the discovery of abnormal ornithine transcarbamylase (OTC, E.C.: 2.1.3.3) in mutant mice bearing the $\mathrm{X}$-chromosomal spf gene. The abnormal liver enzyme from spf/Y males had only $22 \%$ of normal specific activity.
Mixtures of normal and abnormal enzyme activities were seen in heterozygous (spf/+) females. Urinary bladder stones from hemizygous affected males were found to be composed mostly of orotic acid, a metabolite associated with OTC deficiency in human beings (14). It was suggested that spf-bearing mice could serve as a model for studying measures to alleviate the consequences of OTC deficiency in children.

Because we have been investigating a case of OTC deficiency $(2,17)$, we established a colony of spf mice in order to study their suitability as research models of OTC deficiency in children.

\section{MATERIALS AND METHODS}

\section{ANIMAL BREEDING}

All the mice mentioned are descendants of eight untested females $(+/+$ or $\mathrm{spf} /+)$ and two strain $22 \mathrm{~A}$ males $(+/ \mathrm{Y})$, kindly supplied by Dr. L. B. Russell (Demars et al. (9)). Four females were kept with each of the two males. They were fed on Purina Mouse Chow (22). At the end of 3 weeks, the cages were checked regularly for pregnant females which were removed to a separate cage. After delivery, four of the females giving birth to furless progeny were marked as heterozygotes (spf/t). The period before weaning was stretched to 4 weeks to give sufficient time to furless males to adjust. Mothers were remated with original males $(+/ \mathrm{Y})$ after weaning. We were, thus, able to get four crossings per tested female heterozygote. The progeny were sexed and kept in separate groups until ready for enzymatic and biochemical studies.

\section{ENZYMATIC STUDIES}

Fed mice selected for enzymatic studies were decapitated and their liver removed within $2 \mathrm{~min}$. The liver was immediately frozen on dry ice and stored at $-70^{\circ} \mathrm{C}$ until analyzed for enzyme activity. All animals killed for enzymatic studies were of the same age group, i.e., 4-6 weeks postweaning.

Ornithine transcarbamylase was measured in a distilled water homogenate by the colorimetric method of Ceriotti (7), adapted to liver tissue. Before use, the crude homogenate was centrifuged at low speed to separate unbroken cells, membranes, and nuclei. Urease was eliminated from the incubation mixture, because the blanks with or without it were almost colorless. The $\mathrm{pH}$ of the veronal-acetate buffer was adjusted at 7.7 , to ensure optimum activity. Due to the instability of carbamyl phosphate, the substrate mixture was prepared just before use and kept on crushed ice. The mixture contained a final concentration of $5 \mathrm{mM}$ ornithine and $10 \mathrm{mM}$ carbamyl phosphate, for point activity measurements. Aliquots of 1:500 to 1:2000 dilution of liver homogenate were used, depending on the expected enzyme activity in the sample. The amount of liver protein per tube ranged between 5-20 $\mu \mathrm{g}$. 
Incubation was for $10 \mathrm{~min}$ at $37^{\circ} \mathrm{C}$. Gloves were employed during the entire operation to avoid contamination with urea from perspiration.

For kinetic studies, the substrate concentration was varied between $0.66 \mathrm{mM}$ to $10 \mathrm{mM}$ ornithine or carbamyl phosphate, while keeping the cosubstrate constant at $10 \mathrm{mM}$ carbamyl phosphate or $5 \mathrm{mM}$ ornithine, respectively. Activity at each substrate concentration was plotted on a graph before calculating $K_{m}$ and $\mathbf{V}_{\max }$ values on the basis of a double reciprocal plot.

All enzyme activity values are expressed as $\mu$ mole of citrulline produced $/ \mathrm{mg}$ liver protein $/ \mathrm{hr}$. Liver protein was measured by the method of Lowry et al. (15).

\section{MEASUREMENT OF URINARY METABOLITES}

The mutant mice were so small (less than $20 \mathrm{~g}$ ), that our attempts to collect even a few drops of urine in rodent metabolic cages were unsuccessful. A technique to collect urine spots on filter paper was, therefore, employed. Mice were fasted for $2 \mathrm{hr}$ to equilibrate their metabolic state; and then kept in normal cages, lined with filter paper at the bottom covered with a fibreglass mosquito-netting grill. Filter papers were removed after $4 \mathrm{hr}$ and dried overnight. Urine spots were cut out with scissors under a UV lamp, and reduced to strips of $0.2 \mathrm{~cm}$ width. The strips were eluted in $10-15 \mathrm{ml}$ of $0.1 \mathrm{~N} \mathrm{HCl}$ in a mechanical shaker (Eberbach), at $4^{\circ} \mathrm{C}$ for $30 \mathrm{~min}$. Tubes containing eluted strips were centrifuged to remove the supernatant.

The eluate was analyzed for orotic acid, urea, and creatinine. Orotic acid was measured by the colorimetric method of Adachi et al. (1), with provision of nonbrominated blanks for each sample tube as proposed by Goldstein et al. (11). Urea was measured by the technique of Ceriotti (8) and creatinine by the technique of Jaffe (23). Results were expressed as $\mu$ moles of orotic acid or $\mathrm{m}$ moles of urea per mg of creatinine.

Although high recovery rates of various metabolites were generally obtained, we included control filter papers with standard quantities of metabolite solutions absorbed on them, with each batch of analysis. Recovery factors were calculated each time to adjust the observed values.

\section{STATISTICAL ANALYSES}

Significance between means of various groups in respect of enzymatic parameters or urinary metabolite excretion was analyzed by the Student's $t$ test.

\section{RESULTS}

\section{ANIMAL BREEDING}

Figure 1 shows the results of 16 crossings from matings of four $\mathrm{spf} /+$ females and two $22 \mathrm{~A}+/ \mathrm{Y}$ males. A total of 84 young ones were born. The observed progeny, classified according to spf phenotype for the males and orotic acid excretion/enzyme activity for the females, generally follow the X-linked mode of inheritance. The only practical difficulty was in assigning normal or heterozygote classification for the borderline female cases. We followed the statistical methodology of Westwood and Raine (21), to calculate critical values for such a differentiation; but due to the limitations of the method, it is probable that some normal females might have been assigned to the heterozygote category.

\section{OTC ACTIVITY}

The activity of liver OTC, measured at a substrate concentration of $5 \mathrm{mM}$ ornithine and $10 \mathrm{mM}$ carbamyl phosphate, for various groups of mice is presented in Figure 2. The activity of $15.2 \pm$ $1.32 \mu \mathrm{mole}$ citrulline/mg protein/hr shown by hemizygous affected males, is $13 \%$ of that shown by normal males (114.9 \pm 27.1 $\mu$ mole). Heterozygous females $(63.9 \pm 23.1 \mu$ mole $)$ show a much wider variation with a mean activity of $56 \%$ of that shown by normal females (114.4 $\pm 11.5 \mu$ mole). A critical value of 91.6 was
BREEDING OF SPF MICE

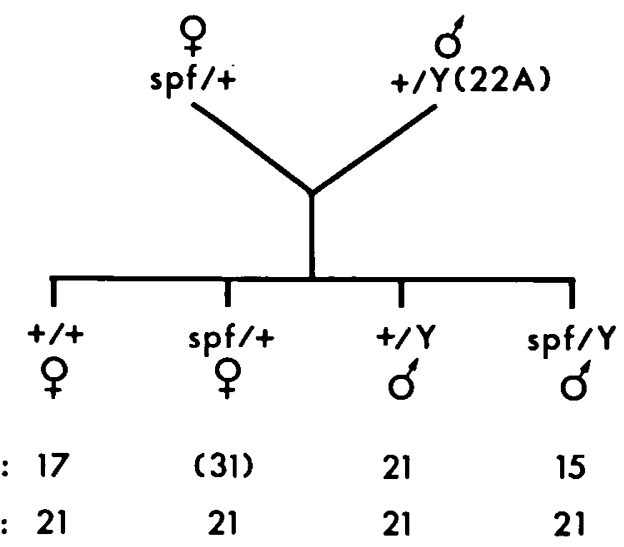

Fig. 1. Classification of progeny obtained from 16 crossings between four heterozygous females and two normal males. Males were separated by the spf phenotype, whereas females were classified according to the OTC activity/urinary orotic acid excretion criteria. Parenthesis in the spf/ + category indicates the possibility of misclassification of borderline cases. + sign represents the normal X-linked gene.

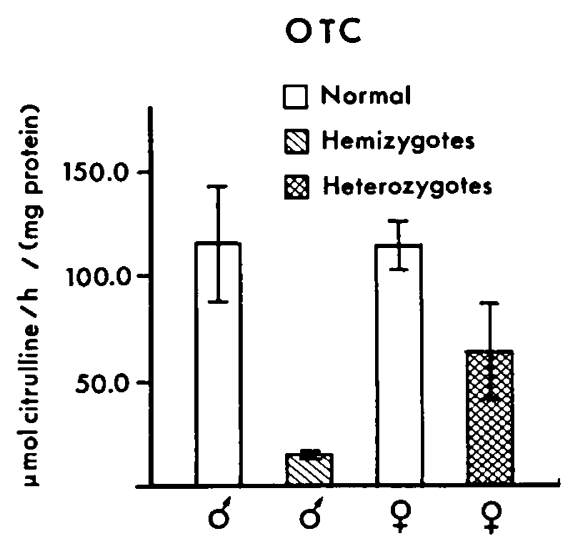

Fig. 2. Point activity of ornithine transcarbamylase in various groups of progeny. The columns represent mean activity with standard deviation as bars. Numbers of animals in each group are the same as Table 1.

calculated on the basis of the results obtained for the two female groups. Those having activity in excess of this value were grouped among normals. However, this value may further have to be scaled down as the lowest value recorded for males was 80.6 . For the purpose of the present paper, the division based on the calculated critical value would be maintained.

\section{KINETICS OF LIVER OTC}

Apparent $K_{m}$ and $V_{\max }$ of the liver OTC in respect of each of the two substrates, CP and ORN, were measured for the four groupings established on the basis of point activity measurements, described previously. $K_{m}$ and $V_{\max }$ values for each animal were obtained separately. Table 1 gives the mean values of each group with calculated standard deviation.

Apparent $\mathrm{K}_{\mathrm{m}}(\mathrm{CP})$ for hemizygous affected males is significantly lower than normal males, normal females, and heterozygous females $(P<0.001)$. The values for heterozygous females are also significantly lower than normal males and females $(P<0.001)$. The significant differences among groups follow the same trend in respect of $V_{\max }(\mathrm{CP})$ values.

There are no significant differences for the values of apparent $\mathrm{K}_{\mathrm{m}}(\mathrm{ORN})$ among various groups. However, the $\mathrm{V}_{\max }(\mathrm{ORN})$ of hemizygous males is significantly lower than the other three 
Table 1. Kinetic studies on ornithine transcarbamylase

\begin{tabular}{|c|c|c|c|c|c|}
\hline \multirow[b]{2}{*}{ Group } & \multirow[b]{2}{*}{$n$} & \multicolumn{2}{|c|}{ Carbamyl Phosphate } & \multicolumn{2}{|c|}{ Ornithine } \\
\hline & & $K_{m}(m M)$ & $\begin{array}{c}\mathrm{V}_{\text {max }}(\mu \text { mole cit } / \mathrm{mg} \\
\text { protein/hr })\end{array}$ & $K_{m}(m M)$ & $\begin{array}{c}V_{\max }(\mu \text { mole cit } \\
\text { protein/hr })\end{array}$ \\
\hline Normal males & 9 & $0.95 \pm 0.3^{1}$ & $121.8 \pm 37.9$ & $1.67 \pm 0.29$ & $156.6 \pm 41.8$ \\
\hline Hemizygous affected males & 6 & $0.09 \pm 0.03$ & $14.3 \pm 1.8$ & $2.09 \pm 0.67$ & $21.1 \pm 3.6$ \\
\hline Normal females & 9 & $0.99 \pm 0.26$ & $123.3 \pm 17.1$ & $1.65 \pm 0.20$ & $149.7 \pm 16.2$ \\
\hline Heterozygous females & 13 & $0.45 \pm 0.28$ & $65.2 \pm 25.4$ & $1.40 \pm 0.4$ & $84.4 \pm 33.2$ \\
\hline
\end{tabular}

${ }^{\prime} \overline{\mathrm{X}} \pm \mathrm{SD}$.

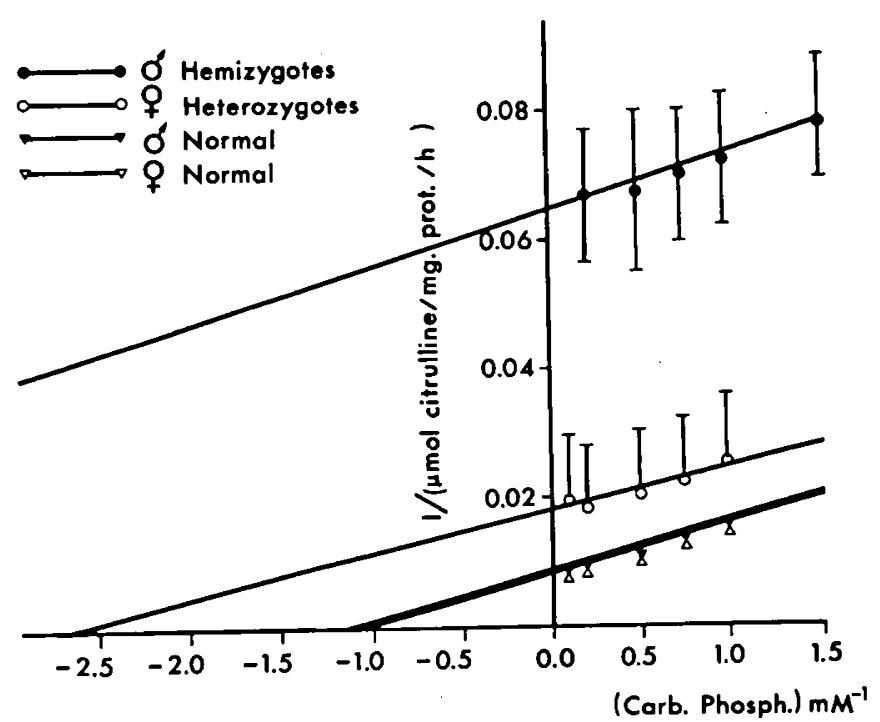

Fig. 3. Lineweaver-Burk plot of OTC activity as a function of $\mathrm{CP}$ concentration. Each point corresponds to the mean of reciprocals of activity obtained at each concentration with bars corresponding to standard deviation (SD). The two normal groups appear as a fused line at the scale used to compare all groups, with representations of SD being impracticable. Calculated $K_{m}(C P)$ and $V_{\max }(C P)$ values are: male affected hemizygotes: $0.14 \mathrm{mM}, 14.1 \mu$ mole; female heterozygotes: $0.37 \mathrm{mM}, 53.1$ $\mu$ mole; male normals: $0.89 \mathrm{mM}, 112.9 \mu$ mole; female normals: $0.97 \mathrm{mM}$, $121.3 \mu \mathrm{mole}$.

groups $(P<0.001) . V_{\max }(\mathrm{ORN})$ of the heterozygous females is also lower than the normal groups $(P<0.001)$.

Means and SD of the reciprocal values of enzyme activity, obtained at each substrate concentration from all animals comprising various groups, were also plotted in the form of Lineweaver-Burk plots. These are presented in Figures 3 and 4 for the $C P$ and ORN variables, respectively. Values of $K_{m}$ and $V_{\max }$ for each of the two substrates follow the same trends as apparent in Table 1 .

\section{EXCRETION OF URINARY OROTIC ACID}

Results of urinary orotic acid excretion from 82 mice, including those bred from four normal $+/+$ females received from Oakridge, are shown in Table 2 . The mean of $18.38 \pm 5.13 \mu$ mole orotic acid/mg creatinine excreted by four surviving hemizygous males was significantly higher than all other groups $(P<0.001)$. The average excretion of $7.38 \pm 5.63 \mu$ mole by heterozygous females, although showing high variability, was also significantly higher than the normal males $(0.72 \pm 0.23 \mu$ mole) and females $(0.54 \pm$ $0.27 \mu$ mole).

In order to separate normal females from heterozygous females, a critical value of $1.25 \mu \mathrm{mole} / \mathrm{mg}$ creatinine was used. Due to practical difficulties involved in assigning borderline cases, it is possible that some overlapping might have occurred. All animals assigned as heterozygotes on the basis of orotic acid excretion are, however, being bred further. This will help in verifying the critical value, as real heterozygotes would produce spf hemizygous males.

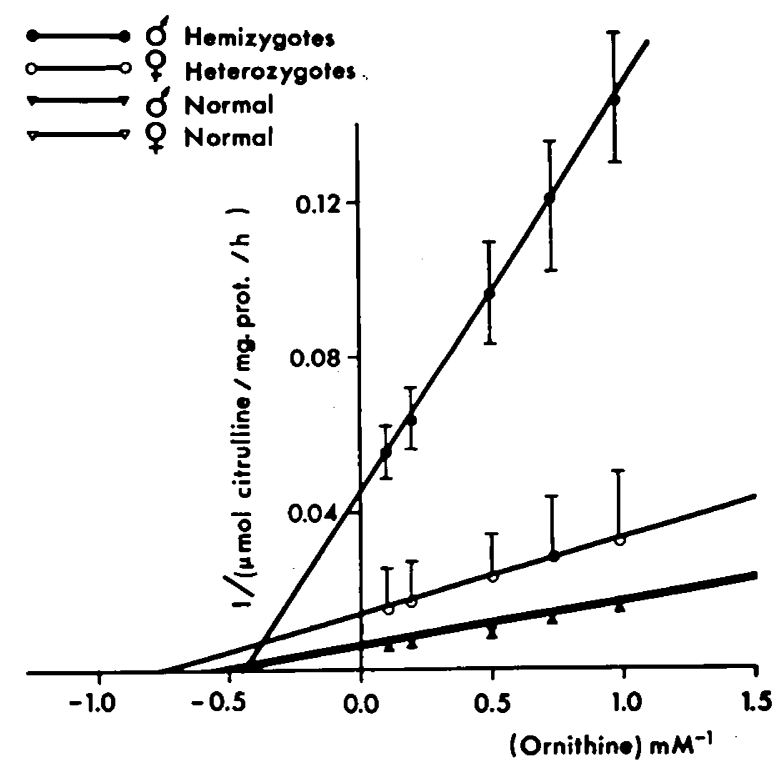

Fig. 4. Lineweaver-Burk plot of OTC activity as a function of ORN concentration. Each point corresponds to the mean of the reciprocals of activity obtained at each concentration with bars corresponding to the standard deviation (SD). The two normal groups appear as a fused line at the scale employed, with representations of SD being impracticable. Calculated $K_{m}(O R N)$ and $V_{\max }(O R N)$ values are: male affected hemizygotes: $2.21 \mathrm{mM}, 21.6 \mu$ mole; female heterozygotes: $1.32 \mathrm{mM}, 69.0 \mu$ mole; male normals: $1.64 \mathrm{mM}, 148.4 \mu$ mole; female normals: $1.62 \mathrm{mM}, 147.6$ $\mu$ mole.

\section{EXCRETION OF URINARY UREA}

There was a wide variation in the excretion of urinary urea, particularly in the affected hemizygous males and heterozygous females (Table 2). However, no statistical significance was seen between the normal males and affected hemizygous males or between normal females and heterozygous females.

\section{DISCUSSION}

The suggestion of Demars et al. (9), that the OTC deficient spfbearing mice could serve as models of human disease, has opened up numerous possibilities for research in hereditary hyperammonemias of children. The mode of inheritance of the spf gene, as also confirmed by breeding results in the present study (Fig. 1), is $\mathrm{X}$-linked as is the inheritance of OTC deficiency hyperammonemia in children (19). We found the activity of liver OTC at pH 7.7 to be $13 \%$ of normal in hemizygous affected males, and $56 \%$ of normal in heterozygous females (Fig. 2). The original paper (9) has mentioned $22 \%$ of activity in spf/Y males, at $\mathrm{pH} 7.6-8.0$. The higher variability of OTC activity in heterozygous females, shown in our study, is in line with the phenomenon of lyonization seen in the X-linked mode of inheritance (18).

Before these mice could be used as a basis for organized studies in human disease, the research base needs to be broadened further. There exists almost no information on the normal or disturbed 


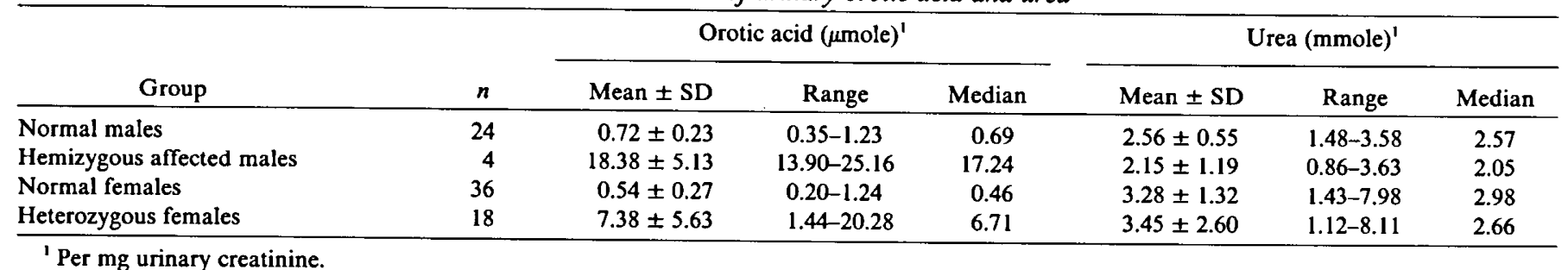

' Per mg urinary creatinine.

metabolic profile of these animals, which could help establish a biochemical phenotype for in vivo studies. It would be necessary to study essentially the nitrogen metabolism of these mice in all its aspects, including the enzyme patterns, formation and excretion of nitrogenous metabolites, etc. Our preliminary studies have dealt with two specific aspects having a direct bearing on the problem, i.e., characterization of the enzyme defect and the suitability of orotic acid excretion as an index of the biochemical phenotype.

Demars et al. (9) reported studies done on the $\mathrm{pH}$ dependence characteristics of the normal and mutant liver enzymes. The normal enzyme in males and females had a maximum activity at $\mathrm{pH}$ 10.0. They also reported that there was a general variation of response between the normal and mutant enzyme activity as a function of the concentration of $\mathrm{L}$-ornithine, at $\mathrm{pH} 8.4$. The studies on the variation of response as a function of carbamyl phosphate concentration were reported to be not conclusive.

The kinetic studies presented by us (Table 1, Figs. 3 and 4), show a significantly lower $K_{m}$ for carbamyl phosphate in the hemizygous males. This might be a characteristic of the mutant enzyme in that there is an abnormal affinity for this substrate at the binding sites, thus, lowering the maximal capacity of catalysis $\left(V_{\max }\right)$. The $K_{m}(O R N)$ is not significantly higher in spf/Y males, but the lower $V_{\max }(\mathrm{ORN})$ reflects the deranged catalysis caused by a marked reduction in the $K_{m}$ for carbamyl phosphate, the cosubstrate necessary for synthesis of citrulline. Unutilized carbamyl phosphate would, therefore, leak out of the mitochondria, where the induction of cytosolic pyrimidine pathway would result in the accumulation of orotic acid.

It would be unrealistic at this stage to draw strict analogies with the human enzyme studies. However, the summary of kinetic details for OTC deficient patients prepared by Gray et al. (12), shows a diverse heterogeneity of mutant enzymes as expressed by altered $\mathrm{K}_{\mathrm{m}}$ values. There are male and female cases reported by Cathelineau et al. (6) and Thaler et al. (20), in which $\mathrm{K}_{\mathrm{m}}(\mathrm{ORN})$ is increased 18-100 times with a 2- to 3- fold reduction in $\mathrm{K}_{\mathrm{m}}$ (CP). On the other hand, the three female cases reported by Cathelineau et al. (5) and Matsuda et al. (16), show a 2-4 times increase in $K_{m}(C P)$ with a slight reduction in $K_{m}(O R N)$. Other cases reported by Levin et al. (13) and Campbell et al. (4), show a reduction of either $K_{m}(C P)$ or $K_{m}(O R N)$.

The situation is further made complex by the recent study of Glasgow et al. (10), which shows that the OTC activity measured in small biopsy specimens from female heterozygotes may not be representative, as it shows a coefficient of variation of $76-96 \%$. This variability is due to mosaic patches of normal or abnormal cells in different areas of liver (18). The same level of variation could be expressed in the kinetic studies done on these samples. The situation could only be clarified when studies made on purified enzyme obtained from affected hemizygous males may be possible.

Whatever structural defect the mutant enzyme may possess, reduced utilization of carbamyl phosphate would result in accumulation of orotic acid. However, this metabolite has a high clearance rate and is immediately excreted in urine. This is supported by the increased orotic acid excretion in almost every case of OTC deficiency in humans, in which a measurement was attempted. The high orotic acid excretion by mutant mice underlines the basic similarity of these animals to the human counterpart.
Although no studies on hyperammonemia in mutant mice were possible due to their extremely small size, the parallelism drawn between the animal and human disorders is valid on the basis of excessive orotic acid excretion. In urea cycle enzyme deficiencies, the metabolic source of blood ammonia as well as orotic acid is carbamyl phosphate (3), which particularly accumulates in OTC deficiency.

Our study on 82 living animals shows that the normal excretion of orotic acid is quite low in males as well as females (Table 2). The affected hemizygous males show a 25 times higher excretion, whereas the heterozygous females give an average of 14 times higher output. The wide variation of orotic acid excretion in heterozygous females reflects the level of enzyme deficiency in individuals or variations in protein intake. These animals may be selective towards a low protein intake. The fact that the hemizygous and heterozygous mice excreted significantly higher quantities of urinary orotic acid than normal animals, on minimal or selectively minimal protein intake, proves the suitability of this index of the biochemical phenotype. Our data are important in the establishment of a biochemical criterion for distinguishing between normal and heterozygous females. This would also form the basis of our further nutritional and metabolic studies.

\section{REFERENCES AND NOTES}

1. Adachi, T., Tanimura, A., and Asahina, M.: A colorimetric determination of orotic acid. J. Vitaminol., 9: 217 (1963).

2. Beaudry, M. A., Letarte, J., Collu, R., Leboeuf, G., Ducharme, J. R., Melancon, S. B., and Dallaire, L.: Hyperammoniemie chronique avec acidurie orotique: Stimulation de la voie des pyrimidines. Diabète et Métabolisme, 1: 29 (1975).

3. Brusilow, S., Batshaw, M., Robinson, B., Sherwood, G., and Walser, M.: The mechanism of hyperammonemia in citrullinemia. Pediatr. Res. (abstract) 11 : 453 (1977).

4. Campbell, A. G. M., Rosenberg, L. E., Snodgrass, P. J., and Nuzum, C. T.: Ornithine transcarbamylase deficiency: a cause of lethal neonatal hyperammonemia in males. N. Engl. J. Med., 288: 1 (1973).

5. Cathelineau, L., Navarro, J., Aymard, P., Bandon, J. J., Mondet, Y., Polonovski, C., and Laplane, R.: Hyperammoniémie héréditaire par anomalie qualitative de l'ornithine carbamyl transferase hépatique et intestinale. Arch. Franc. Pediatr., 29: 713 (1972).

6. Cathelineau, L., Saudubray, J. M., and Polonovski, C.: Ornithine carbamyl transferase: the effects of $\mathrm{pH}$ on the kinetics of a mutant human enzyme. Clin. Chim. Acta, 41: 305 (1972)

7. Ceriotti, G.: Optimal conditions for ornithine carbamyl transferase determination. A simple micromethod without deproteinisation. Clin. Chim. Acta, 47: 97 (1973).

8. Ceriotti, G.: Ultramicro determination of plasma urea by reaction with diacetyl monoxime antipyrine without deproteinization. Clin. Chem., 17: 400 (1971).

9. Demars, R., Levan, S. L., Trend, B. L., and Russell, L. B.: Abnormal ornithine carbamyl transferase in mice having the sparse-fur mutation. Proc. Nat. Acad. Sci. U.S.A., 73: 1693 (1976).

10. Glasgow, A. M.: Metabolic portosystemic shunts in ornithine transcarbamylase deficiency. Pediatr. Res., (abstract) 11: 456 (1977).

11. Goldstein, A. S., Hoogenraad, N. J., Johnson, J. D., Fukanaga, K., Swierczewski, E., Cann, H. M., and Sunshine, P.: Metabolic and genetic studies of a family with ornithine transcarbamylase deficiency. Pediatr. Res., 8: 5 (1974).

12. Gray, R. G. F., Black, J. A., Lyons, V. H., and Pollitt, R. J.: Ornithine transcarbamylase deficiency: enzyme studies on a further case and a method of diagnosis using plasma values. Pediatr. Res., 10: 918 (1976).

13. Levin, B., Dobbs, R. H., Burgess, E. A., and Palmer, T.: Hyperammonemia: a variant type of deficiency of liver ornithine transcarbamylase. Arch. Dis. Childhood, 44: 162 (1969).

14. Levin, B., Oberholzer, V. G., and Sinclair, R. L.: Biochemical investigations of hyperammonemia. Lancet 2: 170 (1969).

15. Lowry, O. H., Rosebrough, N. J., Farr, A. L., and Randall, R. J.: Protein measurement with the folin-phenol reagent. J. Biol. Chem., 193: 265 (1961).

16. Matsuda, I., Arashima, S., Nambu, H., Takekoshi, Y., and Anakura, M.: Hyper- 
ammonemia due to a mutant enzyme of ornithine transcarbamylase. Pediatrics, 48: 595 (1971).

17. Qureshi, I. A., Letarte, J., and Ouellet, R.: Study of enzyme defect in a case of ornithine transcarbamylase deficiency. Diabète et Métabolisme 4: 239 (1978)

18. Ricciuti, G. C., Geleherter, T. D., and Rosenberg, L. E.: X-chrom.Jsome inactivation in human liver. Confirmation of X-linkage of ornithine transcarbamylase. Am. J. Human Gen., 28: 332, (1976).

19. Short, E. M., Conn, H. O., Snodgrass, P. J., Campbell, A. G. M., and Rosenberg, L. E. Evidence for X-linked dominant inheritance of ornithine transcarbamylase deficiency. N. Engl. J. Med., 288: 7 (1973).

20. Thaler, M. M., Hoogenraad, N. J., and Boswell, M.: Reye's Syndrome due to a protein tolerant variant of ornithine transcarbamylase deficiency. Lancet 2 : 438 (1974).

21. Westwood, A., and Raine, D. N.: Some problems of heterozygote recognition in inherited metabolic disease with special reference to phenylkenonuria. In: J. W. T. Seakins, R. A. Saunders and C. Toothill: Treatment of Inborn Errors of Metabolism. Proceeding of the 10th Symposium of Society for the Study of Inborn Errors of Metabolism. p. 63 (Churchill, Livingstone, London, 1973).
22. Ralston Purina Co. St. Louis, Mo., 63188 (USA).

23. Beckman/Spinco: Model 150 ultra-micro analytical system. Technical Bulletin \#6080 E. Creatinine. Beckman Instruments Co., (USA) (1961).

24. These results were reported in part at the annual meeting of Le Club de Recherche Clinique du Québec, La Malbaie, Québec. October 31, 1977.

25. The authors thank Dr. Neil R.M. Buist for reviewing the manuscript, Mme. Françine Poisson for excellent technical assistance, and the expert secretarial assistance by Mme. Elizabeth B. Cordeau, and Ms. Denyse Drouin.

26. This research was supported in part, by the Fondation Justine Lacoste-Beaubien, Montréal, Québec, and the Quebec Network of Genetic Medicine.

27. Dr. Qureshi is recipient of a research fellowship from the Conseil de la Recherche en Santé du Québec, Montréal (Canada).

28. Requests for reprints should be addressed to: J. Letarte, M.D., Laboratoire d'Endocrinologie, Métabolisme et Nutrition, Centre de Recherche Pédiatrique, Hôpital Sainte-Justine, 3175 chemin Sainte-Catherine, Montréal, P.Q., H3T IC5 (Canada).

29. Received for publication January 19, 1978.

30. Accepted for publication July 14, 1978.

Copyright (C) 1979 International Pediatric Research Foundation, Inc. 0031-3998/79/1307-0807 \$02.00/0 